\title{
Development of a Highly Sensitive Extractive Spectrophotometric Method for the Determination of Nickel(II) from Environmental Matrices Using 2-Acetylpyridine-4-methyl-3-thiosemicarbazone
}

\author{
Desam Nagarjuna Reddy ${ }^{1,2^{*}}$, Kanumukkala Vasudeva Reddy², Berhanu Menasbo Tegegne², \\ Vanka Krishna Reddy ${ }^{3}$ \\ ${ }^{1}$ Department of Chemistry, Analytical Division, College of Natural and Computational Sciences, Mekelle University, Mekelle, Ethiopia \\ ${ }^{2}$ Department of Chemistry, Government Degree College for Women, Chintamani, Karnataka \\ ${ }^{3}$ Department of Chemistry, Analytical Division, Sri Krishnadevaraya University, Anantapur, India \\ Email: ${ }^{2}$ dndnrchem@gmail.com
}

Received April 19, 2012; revised May 24, 2012; accepted June 5, 2012

\begin{abstract}
Nickel(II) reacts with 2-acetylpyridine-4-methyl-3-thiosemicarbazone (APMT) and forms a yellow colored complex, which was extracted into $\mathrm{n}$-hexanol from sodium acetate and acetic acid buffer at $\mathrm{pH}$ 6.0. The absorbance value of the $\mathrm{Ni}(\mathrm{II})-\mathrm{APMT}$ complex was measured at different intervals of time at $375 \mathrm{~nm}$ to ascertain the time stability of the complex. The extraction of the complex into the solvent was instantaneous and stable for more than $72 \mathrm{hrs}$. The system obeyed Beer's law in the concentration range of $0.235-2.43 \mu \mathrm{g} \cdot \mathrm{ml}^{-1}$ of nickel(II), with an excellent linearity and a correlation coefficient of 0.999 . The molar absorptivity and Sandell's sensitivity of the extracted species were found to be $2.16 \times 10^{4} \mathrm{~L} \mathrm{~mol}^{-1} \cdot \mathrm{cm}^{-1}$ and $0.003 \mu \mathrm{g} \cdot \mathrm{cm}^{-2}$ at $375 \mathrm{~nm}$, respectively. Hence a detailed study of the extraction of nickel(II) with APMT has been undertaken with a view to developing a rapid and sensitive extractive spectrophotometric method for the determination of nickel(II) when present alone or in the presence of diverse ions which are usually associated with nickel(II) in environmental matrices like soil and industrial effluents. Various standard alloy samples (CM 247 LC, IN 718, BCS 233, 266, 253 and 251) have been tested for the determination of nickel for the purpose of validation of the present method. The results of the proposed method are comparable with those from atomic absorption spectrometry and were found to be in good agreement.
\end{abstract}

Keywords: Nickel(II); Environmental Matrices; Extractive Spectrophotometry; 2-Acetylpyridine-4-methyl-3-thiosemicarbazone and Atomic Absorption Spectrometry

\section{Introduction}

An important use of nickel in the food industry as a catalyst is evident from its use in the hydrogenation of oils. Nickel is an important element due to its high strength and resistance to corrosion in many media [1]. It is used in nickel plating and also in the manufacture of alloys along with iron, copper, aluminum, chromium, zinc and molybdenum. Nickel containing steels are highly resistant to corrosion. Because of its high melting point $\left(1453^{\circ} \mathrm{C}\right)$, nickel is also used in the production of heatresistant steels and cast iron. Nickel-plated steels are used in the manufacture of some food processing vessels and many other pieces of equipment. Nickel(II) is present in small amounts in most of the soils, plants and animal tissues. The interest in the determination of nickel has

"Corresponding author. grown considerably in recent years, owing to its involvement in some essential metabolic processes [2]. Nickel is relatively non-toxic and does not cause any serious human health hazard, despite the fact that acid foods take up nickel during cooking. The nickel deposited in the human body from nickel vessels is not readily absorbed and causes no detectable hazard. However, a high incidence of respiratory tract neoplasia among workers in nickel refineries and carcinogenic properties of this metal have been reported [1]. Thio- and phenylthiosemicarbazones have a wide range of applications in medicine and agriculture. Owing to the ability of these reagents to form intense colored complexes with various metal ions [3-5] they are widely employed in spectrophotometric and extractive spectrophotometric analysis, atomic absorption spectrometry and solid-liquid separation. The nickel(II)thiosemicarbazone complexes have intense colors and 
high molar absorptivities when compared with the analogous thiosemicarbazone complexes. A literature survey indicated that only a few thiosemicarbazones [6-13] have been explored for the extractive spectrophotometric determination of nickel(II) and 2-acetylpyridine-4-methyl3-thiosemicarbazone (APMT) has so far not been used as an analytical reagent for the extraction of nickel(II). In the present work, APMT has been examined in order to evaluate its usefulness as an extractive spectrophotometric reagent for nickel(II). Further, this method has been applied successfully for the analysis of nickel(II) in environmental matrices like soil and industrial effluents. For the determination of nickel at micro levels there are several frequently adopted methods using analytical techniques such as AAS, ICP-OES, ICP-AES, ICP-MS, X-ray fluorescence spectroscopy, spectrophotometry, spectrofluorometry and other such techniques. Among these, the spectrophotometric methods are preferred as they are cheaper and easier to handle and have comparable sensitivity.

\section{Experimental}

\subsection{Instrumentation}

A Shimadzu 240 UV-VIS spectrophotometer with a 1.0 $\mathrm{cm}$ quartz cell was used for absorbance studies. An Elico LI-120 digital $\mathrm{pH}$ meter was used for $\mathrm{pH}$ adjustment. A Perkin-Elmer 2380 atomic absorption spectrometer was used for the comparison of results.

\subsection{Reagents and Samples}

2-acetylpyridine amounting $0.5 \mathrm{~g}$ was dissolved in 25.0 $\mathrm{ml}$ ethanol and mixed in a flask containing $1.5 \mathrm{~g} \mathrm{4-} \mathrm{me-}$ thyl 3-thiosemicarbazide dissolved in $25.0 \mathrm{ml}$ of a $1: 1$ ethanol-water mixture. The resulting reaction mixture was refluxed in a water bath for $30 \mathrm{~min}$. It was allowed to stand at room temperature until pale yellow crystals were formed [14]. These were separated and recrystallized from ethanol (Scheme 1).

The molecular formula and molecular weight of APMT are $\mathrm{C}_{9} \mathrm{H}_{12} \mathrm{~N}_{4} \mathrm{~S}$ and 250 respectively. The com- pound was characterized by IR and ${ }^{1} \mathrm{H}-\mathrm{NMR}$ spectral data. Infra red spectrum of APMT shows bands at (3288 (s), 3239 (s),
3043 (m), 1577 (s), 1537 (s), 1497 (s), 1364 (w), 1147 (m), $832(\mathrm{~s})$ and $681(\mathrm{~s}) \mathrm{cm}^{-1}$ corresponding to $\mathrm{v}(\mathrm{N}-\mathrm{H})$ (asymmetric and symmetric $), v(\mathrm{C}-\mathrm{H})$ aromatic stretch, $v(\mathrm{C}=\mathrm{N})$ stretching(Schiff base $), v(\mathrm{C}-\mathrm{H})$ aromatic ring, $\mathrm{v}(\mathrm{C}-\mathrm{H})$ of pyridine ring, $\mathrm{v}(\mathrm{N}-\mathrm{H})$ stretch(primary amide), $\mathrm{v}(\mathrm{C}=\mathrm{S})$, $v(\mathrm{C}-\mathrm{H})$-oop bend (aromatic) and $v(\mathrm{C}-\mathrm{C})$-oop bend aromatic ring vibrations. ${ }^{1} \mathrm{H}-\mathrm{NMR}$ spectrum of APMT $\left(\mathrm{CDCl}_{3}+\mathrm{DMSO}_{-} \mathrm{d}_{6}\right)$ showed signals at $2.39(3 \mathrm{H}, \mathrm{S}), 7.37-$ $8.58(\mathrm{~m})$ due to $\mathrm{C}_{5} \mathrm{H}_{4} \mathrm{~N}$ (pyridine), and 3.24 (s) corresponds to $\mathrm{CH}_{3}$ group attached to nitrogen atom of thiosemicarbazone.

\subsection{Preparation of Standard Solution of Nickel(II)}

$6.73 \mathrm{~g}$ of ammonium nickel sulfate hexahydrate $\left.\left[(\mathrm{NH} 4)_{2} \cdot \mathrm{Ni}\left(\mathrm{SO}_{4}\right)_{2} \cdot 6 \mathrm{H}_{2} \mathrm{O}\right)\right]$ was weighed, dissolved in double-distilled water containing a few drops of concentrated sulfuric acid and made up to one liter. The stock solution was then standardized gravimetrically using dimethylglyoxime[15]. The required dilute solutions of nickel(II) were prepared by diluting the stock solution with doubledistilled water. All reagents used were of analytical reagent grade unless otherwise stated.

\subsubsection{Buffer Solutions}

1.0 M Hydrochloric acid and $1 \mathrm{M}$ sodium acetate $(\mathrm{pH} 0.5-$ 3.0), 0.2 $\mathrm{M}$ of $\mathrm{NaOAc}$ and $0.2 \mathrm{M} \mathrm{AcOH}(\mathrm{pH} 4.0-7.0)$ and $2.0 \mathrm{M} \mathrm{NH} \mathrm{Nl}_{4} \mathrm{Cl} 2.0 \mathrm{M} \mathrm{NH}_{4} \mathrm{OH}(7.0$ - 10.0) buffer solutions were prepared in distilled water. Suitable portions of these solutions are mixed to get the desired $\mathrm{pH}$.

\subsubsection{Collection of Environmental Matrices, Preparation of Solutions and Analytical Procedure}

The environmental matrices (soil and industrial effluents) to be analyzed were collected from around Kadapa, Andhra Pradesh, South India. The dried sample was pulverized in a mortar for the purpose of analysis, to a convenient size. An aliquot of $500 \mathrm{mg}$ of soil in $100 \mathrm{ml}$ of industrial effluent was digested with $5 \mathrm{ml}$ of $\mathrm{HNO}_{3}(65 \%)$ in a Teflon vessel. The sample was digested for $3 \mathrm{hrs}$ at $80^{\circ} \mathrm{C}$, and again digested at $160^{\circ} \mathrm{C}$ for $45 \mathrm{~min}$. After treating with double-distilled water the supernatant liquid was made up to the mark in a $25 \mathrm{ml}$ standard flask.<smiles>CC(=O)c1ccccn1</smiles><smiles>CNC(=S)NN</smiles>

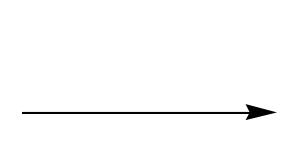

\section{2-acetylpyridine 4-methyl 3-thiosemicarbazide}

2-acetylpyridine-4-methyl-3thiosemicarbazone

Scheme 1. Synthesis of 2-acetylpyridine-4-methyl-3-thiosemicarbazone (APMT). 


\subsubsection{Analytical Procedure for Standard Alloy Samples}

A total of $0.1 \mathrm{~g}$ of each oven-dried $\left(110^{\circ} \mathrm{C}\right)$ alloy sample was dissolved in $15 \mathrm{ml}$ of aqua regia. The solution was heated to near dryness and nitrate was expelled from the residue using $5 \mathrm{ml}$ of concentrated hydrochloric acid. Each residue was extracted into double-distilled water separately and made up to $100 \mathrm{ml}$.

\subsubsection{General Procedure}

To an aliquot of a working standard solution containing $0.1-10 \mu \mathrm{g} \cdot \mathrm{ml}^{-1}$ nickel(II) were added $\mathrm{pH} 6.0$ buffer (3 $\mathrm{ml}), 1 \times 10^{-3} \mathrm{M}$ reagent solution $(1 \mathrm{ml})$ and a salting-out agent, $0.1 \mathrm{M}$ magnesium sulfate $(1 \mathrm{ml})$. The mixture was shaken two times with $10 \mathrm{ml}$ portions of $\mathrm{n}$-hexanol each time for $1 \mathrm{~min}$ and allowed to stand for a few minutes. The two organic phases were collected into a $25.0 \mathrm{ml}$ volumetric flask and made up to the mark with n-hexanol. The absorbance for all the organic phases was measured at $375 \mathrm{~nm}$ against the reagent blank.

\section{Results and Discussion}

\subsection{Absorption Spectra of the Reagent and Ni(II)-APMT Complex}

An aliquot of $1.0 \mathrm{ml}$ of $4 \times 10^{-5} \mathrm{M}$ nickel(II) solution was transferred into a $25 \mathrm{ml}$ separating funnel and to it; $3.0 \mathrm{ml}$ of buffer (pH 6.0) and $1.0 \mathrm{ml}$ of $4 \times 10^{-4} \mathrm{M}$ APMT solutions were added. The absorption spectrum of the reagent solution against the solvent blank, and the absorption spectrum of the solution containing nickel(II) complex against the reagent blank, were recorded. From the spectra, it is clear that the Ni(II)-APMT complex and the reagent have maximum absorbance at 375 and $340 \mathrm{~nm}$, respectively. The reagent has a minimum absorbance at the maximum absorbance of the complex and does not interfere in the determination of nickel(II). Hence, further absorbance measurements of the complex were carried out at 375 nm.

\subsection{Effect of $\mathrm{pH}$ on the Extraction of Ni(II)-APMT Complex}

A preliminary study showed that the formation of Ni(II)APMT complex was affected by the hydrogen ion concentration. The optimum $\mathrm{pH}$ range for the absorbance was determined by using buffers such as potassium chloride-hydrochloric acid ( $\mathrm{pH} 1.0$ - 2.6), sodium formateformic acid ( $\mathrm{pH} 2.6$ - 3.4), sodium acetate-acetic acid (pH 3.4 - 6.5) and ammonium chloride-ammonium hydroxide ( $\mathrm{pH} 7.0$ - 11.0). In each case, a mixture containing $1.0 \mathrm{ml}$ of $4 \times 10^{-5} \mathrm{M}$ nickel(II) solution, $3.0 \mathrm{ml}$ of the suitable buffer and $1.0 \mathrm{ml}$ of $4 \times 10^{-4} \mathrm{M}$ of APMT solution were taken into a $25 \mathrm{ml}$ separating funnel and the volume of the aqueous phase adjusted to $10.0 \mathrm{ml}$ with double distilled water. The absorbance for all the organic extracts was measured at $375 \mathrm{~nm}$ using their respective reagent blanks. A graph between $\mathrm{pH}$ and absorbance is given in Figure 1. This indicates that the complex shows maximum absorbance in the $\mathrm{pH}$ range 5.5 - 6.5. so in subsequent studies buffer having $\mathrm{pH} 6.0$ was used.

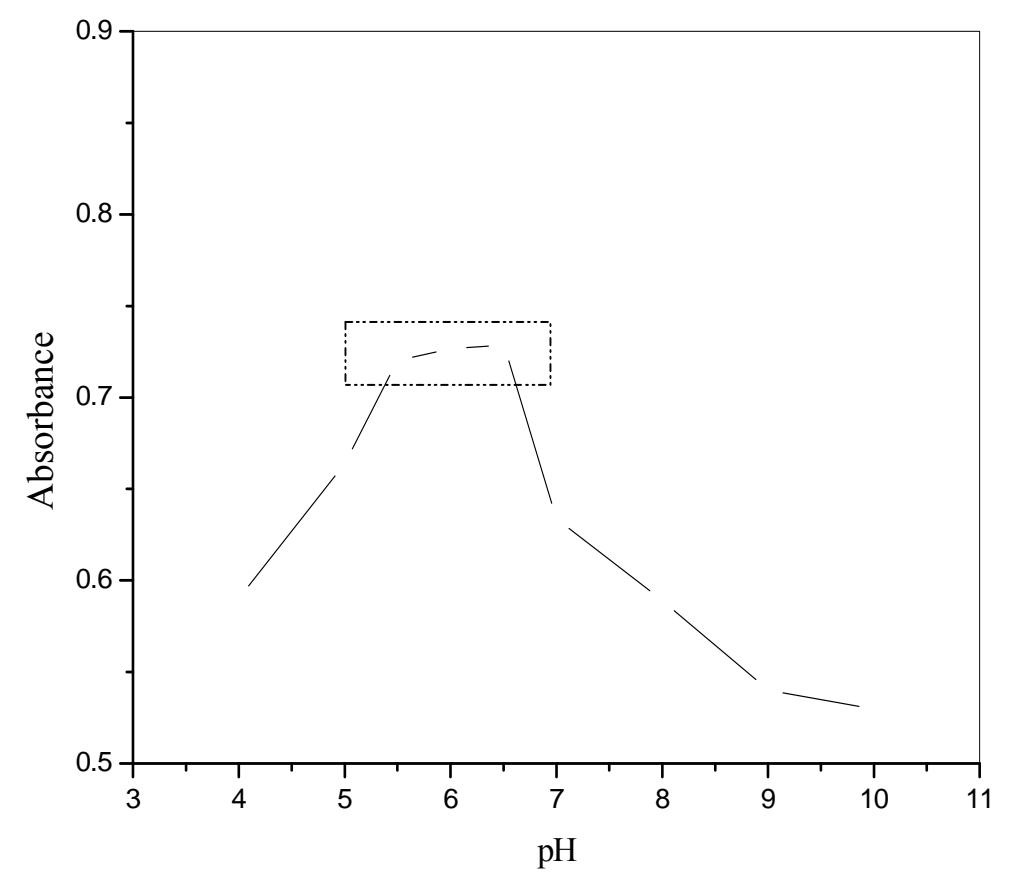

Figure 1. Effect of pH on the absorbance of Ni(II)-APMT complex; Ni(II) $1.0 \mathrm{ml} \mathrm{of} 4 \times 10^{-5} \mathrm{M}$; APMT $1.0 \mathrm{ml} \mathrm{of} 4 \times 10^{-4}$ M. 


\subsection{Effect of Reagent Concentration on the Absorbance of Ni(II)-APMT Complex}

The effect of reagent concentration on the formation of the Ni(II)-APMT complex was studied using $1.0 \mathrm{ml}$ of $4 \times$ $10^{-5} \mathrm{M}$ metal ion solution, $3.0 \mathrm{ml}$ of $\mathrm{pH} 6.0$ buffer and $1.0 \mathrm{ml}$ of APMT solution containing different concentrations ranging from $4 \times 10^{-4} \mathrm{M}$ to $12.03 \times 10^{-4} \mathrm{M}$. The total volumes of the aqueous phases were brought up to $10.0 \mathrm{ml}$ with double-distilled water. The aqueous phases were shaken separately with $10.0 \mathrm{ml}$ of n-hexanol, and the organic phases were collected into $25 \mathrm{ml}$ standard flasks. The organic phases were made up with n-hexanol and the absorbances of these phases were measured at $375 \mathrm{~nm}$, against their corresponding reagent blanks. This study has revealed that a ten-fold molar excess of the APMT to that of nickel is necessary for maximum extraction of the metal ion. Hence, a tenfold molar excess of the reagent was maintained for maximum extraction of nickel(II).

\subsection{Effect of Solvents on the Extraction of Ni(II)-APMT Complex}

Solvents such as isoamylalcohol, n-amylalcohol, n-butanol, n-hexanol, benzene, xylene, chloroform, carbon tetrachloride, cyclohexane, cyclohexanol and methylisobutylketone were examined as extractants. As per the results reported in Table 1, n-butanol was found to be a suitable solvent for the effective extraction of $\mathrm{Ni}(\mathrm{II})$ APMT complex. Hence, n-hexanol was chosen for all further studies.

Table 1. Effect of solvents on the extraction of Ni(II)-APMT complex.

\begin{tabular}{cc}
\hline Solvent & Absorbance \\
\hline n-Amyl alcohol & 0.731 \\
Isoamyl alcohol & 0.672 \\
Benzene & 0.813 \\
n-Butanol & 0.893 \\
n-hexanol & 0.915 \\
Xylene & 0.854 \\
Chloroform & 0.732 \\
Cyclohexanane & 0.681 \\
Cyclohexanol & 0.785 \\
Carbon tetrachloride & 0.793 \\
Methyl isobutyl ketone & 0.641 \\
\hline
\end{tabular}

$\mathrm{Ni}(\mathrm{II}): 1.0 \mathrm{ml}$ of $4 \times 10^{-5} \mathrm{M}$; APMT: $1.0 \mathrm{ml}$ of $4 \times 10^{-4} \mathrm{M}$; pH: $6.0 ; \lambda_{\max }$ : $375 \mathrm{~nm}$.

\subsection{Effect of Salting-Out Agents on the Extraction of Ni(II)-APMT Complex}

Various salting-out agents, such as magnesium sulfate, magnesium nitrate, lithium acetate, lithium sulfate, lithium nitrate and ammonium sulfate were employed to enhance the metal complex extraction into organic solvent in a single step. After the studies, it was observed that the presence of $0.1 \mathrm{M}$ magnesium nitrate solution enhanced the extraction. The presence of nickel(II) in the aqueous phase after extraction was tested gravimetrically by using dimethylglyoxime. It was found that with magnesium nitrate as a salting-out agent, the complex was extracted quantitatively into n-hexanol.

\subsection{Time Stability of the Color Reaction}

The absorbance value of the Ni(II)-APMT complex was measured at different intervals of time at $375 \mathrm{~nm}$ to ascertain the time stability of the color of the complex. It was observed that the color remained constant for more than 72 hrs. Physico-chemical and analytical properties of nickel (II) complex of APMT are summarized in Table 2 .

\subsection{Applicability of Beer's Law to the Ni(II)-APMT Complex System}

Known aliquots of $10.0 \mathrm{ml}$ solutions containing constant volumes of $3.0 \mathrm{ml}$ of buffer ( $\mathrm{pH} 6.0$ ), $1.0 \mathrm{ml}$ of $4 \times 10^{-4}$ M APMT, $1.0 \mathrm{ml}$ of $0.1 \mathrm{M}$ magnesium nitrate solution and varying amounts of nickel(II) ranging from $0.1-10.0$ $\mu \mathrm{g} \cdot \mathrm{ml}^{-1}$ were prepared. Each solution was shaken with $10.0 \mathrm{ml}$ of $\mathrm{n}$-hexanol for $2 \mathrm{~min}$ and then allowed to settle.

The organic phases were collected in different $25.0 \mathrm{ml}$ standard flasks and then made up with n-hexanol. The absorbance for all the organic phases was measured at $375 \mathrm{~nm}$, against their corresponding reagent blanks. From the experimental data, it was found that the complex system obeys Beer's law in the concentration range 0.235 $2.43 \mu \mathrm{g} \cdot \mathrm{ml}^{-1}$ of nickel(II). The straight line obeys the equation $\mathrm{A}_{375}=0.3403 \mathrm{C}+0.0054$. The molar absorptivity and Sandell's sensitivity of the method are $2.16 \times$ $10^{4} \mathrm{~L} \cdot \mathrm{mol}^{-1} \cdot \mathrm{cm}^{-1}$ and $0.003 \mu \mathrm{g} \cdot \mathrm{cm}^{-2}$ of $\mathrm{Ni}(\mathrm{II})$ respectively. The specific absorptivity of the system is found to be $0.368 \mathrm{ml} \cdot \mathrm{g}^{-1} \cdot \mathrm{cm}^{-1}$. The standard deviation in the determination of $1.17 \mu \mathrm{g} \cdot \mathrm{ml}^{-1}$ of $\mathrm{Ni}(\mathrm{II})$ is 0.008 for ten determinations. The relative standard deviation and the mean absorbance are 0.67 percent and $0.4137 \pm 0.0013$ respectively.

\subsection{Determination of the Composition of Ni(II)-APMT Complex}

The composition of the Ni(II) complex with APMT was studied using Job's method of continuous variation, and 
Table 2. Physico-chemical and analytical characteristics of Ni-(APMT) $)_{2}$ complex at glance.

\begin{tabular}{|c|c|c|}
\hline S.No & Characteristics & $\mathrm{Ni}-(\mathrm{APMT})_{2}$ \\
\hline 1 & $\lambda_{\max }(\mathrm{nm})$ & 375 \\
\hline 2 & $\mathrm{pH}$ - range (optimum) & $5.5-6.5$ \\
\hline 3 & Mean absorbance & $0.319 \pm 0.0008$ \\
\hline 4 & Mole of reagent required per mole of metal ion for full color developed & 10 Fold \\
\hline 5 & Time stability of the complex (in hrs) & 72 \\
\hline 6 & Beer's law validity range $\left(\mu \mathrm{g} \cdot \mathrm{ml}^{-1}\right)$ & $0.235-2.43$ \\
\hline 7 & Molar absorptivity $\left(\mathrm{L} \mathrm{mol}^{-1} \cdot \mathrm{cm}^{-1}\right)$ & $2.16 \times 10^{4}$ \\
\hline 8 & Specific absorptivity $\left(\mathrm{ml} \mathrm{g}^{-1} \cdot \mathrm{cm}^{-1}\right)$ & 0.368 \\
\hline 9 & Sandell's sensitivity $\left(\mu \mathrm{g} \cdot \mathrm{cm}^{-2}\right)$ & 0.003 \\
\hline 10 & Composition of complex as obtained jobs and molar ratio methods (M:L) & $1: 2$ \\
\hline 11 & Stability constant of the complex & $8.3 \times 10^{11}$ \\
\hline 12 & Standard deviation in the determination of $1.17 \mu \mathrm{g} \cdot \mathrm{ml}^{-1}$ of $\mathrm{Ni}(\mathrm{II})$ for ten determinations & 0.005 \\
\hline 13 & Relative standard deviation (RSD)\% & 0.677 \\
\hline 14 & Y-Intercept & +0.0129 \\
\hline 15 & Angular coefficient (m) & 0.0919 \\
\hline 16 & Correlation coefficient $(v)$ & 0.999 \\
\hline 17 & Detection limit $\left(\mu \mathrm{g} \cdot \mathrm{ml}^{-1}\right)$ & 0.047 \\
\hline 18 & Determination limit $\left(\mu \mathrm{g} \cdot \mathrm{ml}^{-1}\right)$ & 0.141 \\
\hline
\end{tabular}

the mole ratio method.

Extractive spectrophotometric investigation of the metal complex was conducted to obtain the composition of the complex. The composition of the complex was established by Job's method of continuous variation. Equimolar solutions of nickel(II) and APMT $\left(2 \times 10^{-4} \mathrm{M}\right)$ were prepared. The metal and reagent solutions were mixed in different proportions, keeping the total volume constant at $1.0 \mathrm{ml}$. To each solution, $3.0 \mathrm{ml}$ of buffer $(\mathrm{pH} 6.0)$ solution and $1.0 \mathrm{ml}$ of $0.1 \mathrm{M}$ magnesium nitration solution as salting-out agent were added and the volumes of the aqueous phases brought to $10.0 \mathrm{ml}$ with double-distilled water. Each of the aqueous phases was shaken with $10.0 \mathrm{ml}$ of $\mathrm{n}$-hexanol for $2 \mathrm{~min}$ and allowed to settle. The organic phase was collected into a $25.0 \mathrm{ml}$ standard flask and made up to the mark with n-hexanol. The absorbance values of the organic phases were recorded at $375 \mathrm{~nm}$, against their respective reagent blanks. From the above experimental results, it is evident that one mole of nickel(II) reacts with two mole of APMT, showing the composition of the complex to be $1: 2$. This composition was verified using the molar ratio method. From jobs continuous variation method the stability constant of the complex has been found to be $8.3 \times 10^{11}$.

\subsection{Effect of Foreign Ions on the Extraction of Ni(II)-APMT Complex}

Known amounts of various cations and anions were added to a fixed amount of nickel(II) in order to study the effect of interference of these ions on the extraction and determination of nickel(II), using the analytical procedure described in the Experimental section. An error of $72 \%$ in the absorbance reading was considered to be tolerable. The results are given in Table 3 . Cations like aluminum(III), uranium(VI), indium(III) and iron(II) do not interfere, even when present up to $4000 \mu \mathrm{g} / \mathrm{ml}$. Manganese(II), tungsten(VI), barium(II) and magnesium(VI) do not have any effect up to $2500 \mu \mathrm{g} / \mathrm{ml}$, whereas zinc(II), lead(II), selenium(IV), cerium(IV), copper(II) and palladium(II) interfere seriously with the extraction of nickel(II). Anions like fluoride, chloride, bromide, tartrate, thiosulphate and oxalate do not interfere when present up to $4000 \mu \mathrm{g} / \mathrm{ml}$ or more. Thiocynate, thiourea and phosphate interfere seriously, whereas EDTA masks nickel(II) completely due to the higher stability of the Ni(II)-EDTA complex. Sulfate, acetate and citrate do not interfere when present up to $2000 \mu \mathrm{g} / \mathrm{ml}$. The interference of zinc(II), lead(II) selenium(IV), cerium(IV), copper(II), cadmium(II) and palladium(II) can be eliminated 
Table 3. Effect of foreign ions on the extraction of Ni(II)APMT complex.

\begin{tabular}{|c|c|c|c|}
\hline Foreign ion & $\begin{array}{l}\text { Tolerance limit } \\
\qquad(\mu \mathrm{g} / \mathrm{ml})\end{array}$ & Foreign ion & $\begin{array}{l}\text { Tolerance limit } \\
\qquad(\mu \mathrm{g} / \mathrm{ml})\end{array}$ \\
\hline $\mathrm{Mn}(\mathrm{II})$ & 2500 & Fluoride & 4000 \\
\hline $\mathrm{Al}(\mathrm{III})$ & 4000 & Chloride & 4000 \\
\hline $\mathrm{Pb}(\mathrm{II})$ & - & Bromide & 4000 \\
\hline $\mathrm{W}(\mathrm{VI})$ & 2500 & Tartrate & 4000 \\
\hline $\mathrm{U}(\mathrm{VI})$ & 4000 & Thiocynate & - \\
\hline $\mathrm{Zn}(\mathrm{II})$ & - & Thiosulphate & 4000 \\
\hline $\operatorname{In}(\mathrm{III})$ & 4000 & Thiourea & - \\
\hline $\mathrm{Fe}(\mathrm{II})$ & 4000 & Oxalate & 4000 \\
\hline $\mathrm{Cu}(\mathrm{II})$ & - & Phosphate & - \\
\hline $\operatorname{Pd}(\mathrm{II})$ & - & Acetate & 2000 \\
\hline $\mathrm{Be}(\mathrm{II})$ & 2500 & Citrate & 2000 \\
\hline $\mathrm{Ce}(\mathrm{IV})$ & - & EDTA & - \\
\hline $\mathrm{Se}(\mathrm{IV})$ & - & & \\
\hline $\mathrm{Mo}(\mathrm{VI})$ & 2500 & & \\
\hline $\mathrm{Cd}(\mathrm{II})$ & - & & \\
\hline
\end{tabular}

Ni(II): $200-6800 \mu \mathrm{g} \mathrm{ml}^{-1}$; APMT: $1.0 \mathrm{ml}$ of $4 \times 10^{-4} \mathrm{M} ; \mathrm{pH} 6.0 ; \lambda_{\max }: 375$ $\mathrm{nm}$. by using $1.0 \mathrm{ml}$ of $0.5 \%$ thiosulphate solution.

The present method when compared with other existing spectrophotometric methods Table 4 shows more sensitive and selective. It also offers advantages like reliability and reproducibility in addition to its simplicity, instant color development and low interference. APMT is cheap, stable at high temperatures, and easy to dispense and store. The reagent APMT was more stable when complexed with $\mathrm{Ni}$ (II) and the color of the complex was stable for more than $48 \mathrm{hrs}$. APMT extracts nickel selectively when associated with the following metal ions: Al(III), U(VI), In(III), Fe(II), Mn(II), W(VI), Ba(II), $\mathrm{Mg}(\mathrm{VI})$, fluoride, chloride, bromide, tartrate, thiosulphate and oxalate. APMT is a stable reagent for extractive determination of nickel(II).

\subsection{Applications}

The developed extractive spectrophotometric method for nickel(II) has been successfully applied for its determination in environmental matrices and standard alloy samples.

\subsubsection{Determination of Nickel(II) in Soil Samples}

Soil samples were collected from in and around Kadapa, Ananthapur, AP, India. Each aliquot was analyzed for nickel(II) by the general procedure which was given in the experimental section. Nickel(II) present in soil samples was determined from the calibrated plot (Beer's law plot) using APMT and the results checked by atomic absorption spectrometry Table 5 .

Table 4. Comparison of present method with other reported spectrophotometric methods.

\begin{tabular}{|c|c|c|c|c|c|c|c|}
\hline Reagent & $\mathrm{pH}$ & $\lambda_{\max }$ & $\varepsilon \times 10^{4}$ & $\mathrm{M}: \mathrm{L}$ & $\begin{array}{l}\text { Beer's law } \\
\text { range }\end{array}$ & Remarks & Ref. \\
\hline 2-Oximinodimedone dithiosemicarbazone & 5.8 & 440 & 0.72 & $1: 2$ & $1.0-6.0$ & Less sensitive & 6 \\
\hline Biacetylbis (4-phenyl)-3- thiosemicarbazone & 2.5 & 460 & 0.228 & $1: 1$ & $0.2-2.0$ & Very poor sensitivity & 7 \\
\hline Phthalimidedithiosemi carbazone & 10.0 & 440 & 1.13 & $1: 1$ & $0.11-3.21$ & Less sensitive & 8 \\
\hline Salicylaldehyde thiosemicarbazone & $6.5-7.0$ & 370 & 0.98 & $1: 1$ & $0.4-4.0$ & - & 9 \\
\hline Acenaphthanequinone mono thiosemicarbazone & $6.3-8.4$ & 420 & 0.285 & $1: 2$ & 14.7 & Less sensitive & 10 \\
\hline 2,4-Dihydroxy aceto pheneone thiosmicarbazone & $7.0-8.0$ & 385 & 0.82 & $1: 1$ & $1.0-8.0$ & Very poor sensitivity & 11 \\
\hline $\begin{array}{l}\text { 2-Hydroxy-4-isopropoxy acetophenone } \\
\text { thiosemicarbazone }\end{array}$ & 9.0 & 400 & 0.084 & - & 16.44 & Very poor sensitivity & 13 \\
\hline 2-acetylpyridine-4-methyl-3-thiosemicarbazone & 6.0 & 375 & 2.16 & $1: 2$ & $0.235-2.43$ & Sensitive and selective & P.M \\
\hline
\end{tabular}

$\varepsilon$, molar absorptivity; Ref., reference; P.M., present method. 
Table 5. Determination of nickel(II) in soil samples.

\begin{tabular}{ccccc}
\hline \multirow{2}{*}{ Name of the area } & $\begin{array}{c}\text { Amount of nickel(II) })^{\mathrm{a}} \text { found } \\
\left(\mu \mathrm{g} \cdot \mathrm{ml}^{-1}\right)\end{array}$ & SD & $\begin{array}{c}\text { RSD } \\
(\%)\end{array}$ \\
\cline { 2 - 3 } & AAS method & Present method & & \\
\hline Rayachoty & 24.0 & 23.7 & 0.227 & 0.96 \\
Pamidi & 23.0 & 22.8 & 0.225 & 0.99 \\
Madhanapalli & 20.0 & 19.8 & 0.194 & 0.98 \\
Narpala & 20.0 & 19.5 & 0.175 & 0.90 \\
Vempalli & 20.0 & 19.6 & 0.180 & 0.92 \\
Dhadithota & 21.0 & 20.7 & 0.184 & 0.89 \\
Penuconda & 20.0 & 19.3 & 0.231 & 1.20 \\
S.V. Puram & 19.0 & 18.6 & 0.167 & 0.90 \\
Dharmavaram & 19.0 & 18.2 & 0.145 & 0.80 \\
Madhavaram & 22.0 & 21.9 & 0.219 & 1.00 \\
Reddyvari palli & 22.0 & 21.8 & 0.239 & 1.10 \\
Gooty & 23.0 & 22.9 & 0.286 & 1.25 \\
\hline
\end{tabular}

${ }^{\mathrm{a} A v e r a g e ~ o f ~ f o u r ~ d e t e r m i n a t i o n s . ~}$

\subsubsection{Determination of Nickel(II) in Industrial Effluents}

Industrial effluents were collected from industrial areas in and around Kadapa, Andhra Pradesh, India. An appropriate amount of aliquot was taken for extractive spectrophotometric determination of nickel(II) by the method developed in the present work. The results obtained were confirmed by direct atomic absorption spectrometry Table 6.

\subsubsection{Determination of Nickel(II) in Standard Alloy Samples}

The present method was also applied for the determination of nickel(II) content in standard alloy samples such as nickel base super alloys (CM 247 LC and IN 718), alloy steels (BCS 233 and 266) and low alloy steels (BCS 253 and 251). An appropriate aliquot of each solution was analyzed for nickel(II) employing the recommended procedure given in Materials and methods, using APMT, and the obtained results were checked by direct atomic absorption spectrometry as shown in Table 7.

\section{Conclusion}

Thio- and methylthiosemicarbazones are used in the extractive spectrophotometric determination of nickel(II). In the present investigation, the authors introduced a new reagent, 2-acetylpyridine-4-methyl-3-thiosemicarbazone (APMT) to the field of extractive spectrophotometric determination of nickel(II). The reagent was found to be sensitive when compared to earlier reported reagents. The selectivity of the reagent was further improved by
Table 6. Determination of nickel(II) in industrial effluents.

\begin{tabular}{|c|c|c|c|c|}
\hline \multirow{2}{*}{ Name of the area } & \multicolumn{2}{|c|}{$\begin{array}{l}\text { Amount of nickel(II) } \\
\text { found }\left(\mu \mathrm{g} \cdot \mathrm{ml}^{-1}\right)\end{array}$} & \multirow{2}{*}{$\mathrm{SD}$} & \multirow{2}{*}{ RSD (\%) } \\
\hline & $\begin{array}{l}\text { AAS me- } \\
\text { thod }\end{array}$ & $\begin{array}{l}\text { Present } \\
\text { method }\end{array}$ & & \\
\hline \multicolumn{5}{|l|}{ Rayachoty } \\
\hline Sample 1 & 0.50 & 0.50 & 0.0058 & 1.16 \\
\hline Sample 2 & 0.55 & 0.53 & 0.0057 & 1.08 \\
\hline Sample3 & 0.53 & 0.51 & 0.0060 & 1.19 \\
\hline \multicolumn{5}{|l|}{ Rajampeta } \\
\hline Sample 2 & 0.89 & 0.87 & 0.0084 & 0.96 \\
\hline Sample 2 & 0.94 & 0.94 & 0.0088 & 0.94 \\
\hline Sample 3 & 0.96 & 0.95 & 0.0093 & 0.98 \\
\hline \multicolumn{5}{|l|}{ Ramapuram } \\
\hline Sample 1 & 1.30 & 1.28 & 0.0146 & 1.14 \\
\hline Sample 2 & 1.15 & 1.12 & 0.0119 & 1.06 \\
\hline Sample 3 & 1.24 & 1.20 & 0.0131 & 1.09 \\
\hline \multicolumn{5}{|l|}{ Proddotur } \\
\hline Sample 1 & 0.70 & 0.68 & 0.0064 & 0.94 \\
\hline Sample 2 & 0.65 & 0.63 & 0.0057 & 0.90 \\
\hline Sample 3 & 0.72 & 0.71 & 0.0067 & 0.95 \\
\hline \multicolumn{5}{|l|}{ Yaraguntlla } \\
\hline Sample 1 & 0.60 & 0.59 & 0.0057 & 0.96 \\
\hline Sample 2 & 0.60 & 0.57 & 0.0056 & 0.98 \\
\hline Sample 3 & 0.54 & 0.52 & 0.0055 & 1.05 \\
\hline \multicolumn{5}{|l|}{ Anantapuram } \\
\hline Sample 1 & 1.14 & 1.11 & 0.0128 & 1.15 \\
\hline Sample 2 & 0.99 & 0.92 & 0.0097 & 1.05 \\
\hline Sample 3 & 0.98 & 0.94 & 0.0085 & 0.91 \\
\hline \multicolumn{5}{|l|}{ Madhanapalli } \\
\hline Sample 1 & 0.83 & 0.80 & 0.0090 & 1.13 \\
\hline Sample 2 & 0.70 & 0.70 & 0.0087 & 1.24 \\
\hline Sample 3 & 0.80 & 0.77 & 0.0086 & 1.12 \\
\hline \multicolumn{5}{|l|}{ Dharmavaram } \\
\hline Sample 1 & 1.20 & 1.10 & 0.0121 & 1.10 \\
\hline Sample 2 & 0.95 & 0.92 & 0.0084 & 0.91 \\
\hline Sample3 & 1.14 & 1.10 & 0.0113 & 1.03 \\
\hline
\end{tabular}

${ }^{\mathrm{a}}$ Average of five determinations. 
Table 7. Determination of nickel(II) in soil samples.

\begin{tabular}{|c|c|c|c|c|c|}
\hline \multirow[t]{2}{*}{ Name of sample } & \multirow[t]{2}{*}{ Composition $(\%)$} & \multicolumn{4}{|c|}{ Amount of nickel $(\mathrm{II})^{\mathrm{a}}$ found $\left(\mu \mathrm{g} \cdot \mathrm{ml}^{-1}\right)$} \\
\hline & & $\begin{array}{l}\text { AAS } \\
\text { method }\end{array}$ & $\begin{array}{l}\text { Present } \\
\text { method }\end{array}$ & SD & $\operatorname{RSD}(\%)$ \\
\hline Low alloy steel (BCS 251) & $\mathrm{Ni}, 5.15 ; \mathrm{Mo}, 0.185 ; \mathrm{Mn}, 0.165 ; \mathrm{Co}, 0.007 ;{ }^{\mathrm{b}} \mathrm{Cu}, 0.090$ & 5.14 & 5.11 & 0.0495 & 0.97 \\
\hline Low alloy steel (BCS 253) & $\mathrm{Ni}, 2.92 ; \mathrm{Mo}, 0.94 ; \mathrm{Cr}, 0.34 ; \mathrm{V}, 0.220 ;{ }^{\mathrm{b}} \mathrm{Cu}, 0.495$. & 2.90 & 2.86 & 0.0303 & 1.06 \\
\hline Alloy steel (BCS 266) & $\mathrm{Ni}, 13.3 ; \mathrm{Al}, 7.95 ; \mathrm{Co}, 23.4 ;{ }^{b} \mathrm{Cu}, 3.33$. & 13.27 & 13.25 & 0.1179 & 0.89 \\
\hline $\begin{array}{l}\text { Nickel base super alloy } \\
\text { (CM } 247 \text { LC) }\end{array}$ & $\begin{array}{l}\mathrm{Ni}, 61.91 ; \mathrm{Cr}, 8.1 ; \mathrm{Mo}, 0.5 ; \mathrm{Al}, 5.6 ; \mathrm{Ta}, 3.2 ; \mathrm{Zr}, 0.015 \\
\mathrm{C}, 0.06 ; \mathrm{Co}, 9.0 ; \mathrm{W}, 9.5 ; \mathrm{Ti}, 0.7 ; \mathrm{Hf}, 1.4 ; \mathrm{B}, 0.025\end{array}$ & 61.90 & 61.85 & 0.606 & 0.98 \\
\hline $\begin{array}{l}\text { Nickel base super alloy } \\
\text { (IN 718) }\end{array}$ & Ni, 54.9; Cr, 18; Mo, 3; Fe, 19; Co, 5.1. & 54.89 & 54.87 & 0.515 & 0.94 \\
\hline
\end{tabular}

${ }^{\mathrm{a}}$ Average of five determinations; ${ }^{\mathrm{b}}$ Masked with thiosulphate.

the use of proper masking agents to suppress the interference of diverse metal ions. The results from the present developed method clearly demonstrate the usefulness of APMT as an extracting agent for the determination of nickel(II) in environmental matrices and standard alloy samples.

\section{Acknowledgments}

The authors G. Ramachandra Reddy, A. Babul Reddy and P. Haribabu are highly grateful to University grants commission with special assistant programme (UGCSAP), Government of India, New Delhi for financial assistance in the form of Meritorious Research Fellowship.

\section{REFERENCES}

[1] B. K. Sharma, "Environmental Chemistry," Goel Publishing House, Meerut, 1997.

[2] T. Z. Judith, T. Peter and T. Thomas, "Immunotoxicology of Environment Occupational Metals," School of Medicine, New York, 1998.

[3] K. H. Reddy and D. V. Reddy, "Analytical Data and Comparison of Analytical Potentialities of Thiosemicarbazones and Semicarbazones," Quarterly Chemistry Reviews, Vol. 1, 1985, pp. 47-98.

[4] B. S. Garg and V. K. Jain, "Analytical Applications of Thiosemicarbazones and Semicarbazones," Microchemical Journal, Vol. 38, No. 2, 1988, pp. 144-169.

[5] R. B. Singh and H. Ishii, "Analytical Potentialities of Thiosemicarbazones and Semicarbazones," Critical Reviews in Analytical Chemistry, Vol. 22, No. 5, 1991, pp. 381409. doi:10.1080/10408349108051640

[6] F. Salinas, J. C. J. Sanchez and J. L. Lemus, "Spectrophotometric Study of 2-Oximinodimedone Dithiosemicarbazone-ni(II) Complex. Determination of Ni(II)," Bulletin des Sociétés Chimiques Belges, Vol. 95, No. 4, 1986,

\section{pp. 293-294. doi:10.1002/bscb. 19860950411}

[7] A. G. Asuero, "Spectrophotometric Determination of Nickel with Biacetyl Bis(4-phenyl-3-thiosemicarbazone)," Microchemical Journal, Vol. 28, No. 2, 1983, pp. 198-202.

[8] K. G. Reddy, K. M. M. S. Prakash, K. H. Reddy and D. V. Reddy, "Rapid Spectrophotometric Determination of Nickel(II) Using Phthalimide Dithiosemicarbazone," Acta Ciencia Indica, Series Chemistry, Vol. 10, 1984, pp. 175177.

[9] S. K. Singh, M. Kamini and S. K. Sindhwani, "Spectrophotometric Determination of Cobalt(II), Nickel(II) and Copper(II) with Acenaphthenequinone Monosemicarbazone (AQSC)," Journal of the Chinese Chemical Society (Taipei), Vol. 29, No. 2, 1982, pp. 131-134.

[10] K. H. Reddy and D. V. Reddy, "Analytical Data and Comparison of Analytical Potentialities of Thiosemicarbazones and Semicarbazones," Quarterly Chemistry Reviews, Vol. 1, 1985, pp. 47-98.

[11] A. V. Reddy and Y. K. Reddy, "Sequential Extraction and Determination of Copper and Nickel with 2,4-Ihydroxy Acetophenone Thiosemicarbazone," Talanta, Vol. 33, No. 7, 1986, pp. 617-619. doi:10.1016/0039-9140(86)80141-2

[12] V. A. Jadhav and M. U. Kulkarni, "7-Methl-2-chloroquinoline-3-carbaldehyde Thiosemicarbazone as Analytical Reagent for Copper, Cobalt and Nickel(II)," Journal of the Indian Chemical Society, Vol. 69, No. 5, 1992, pp. 287- 288.

[13] D. K. Desai and K. K. Desai, "2-Hdroxy-4-isopropoxyacetophenone Thiosemicarbazone as a Spectrophotometric Reagent for Nickel(II)," Oriental Journal of Chemistry, Vol. 12, 1996, pp. 203-205.

[14] E. Cristofol, F. Sanchez Rojas and J. M. C. Pavon, "Evaluations of Various N-Phenylthiosemicarbazones as Chromogenic Reagents in Spectrophotometric Analysis," Talanta, Vol. 38, No. 4, 1991, pp. 445-448. doi:10.1016/0039-9140(91)80084-D

[15] A. I. Vogel, "A Text Book of Quantitative Inorganic Analysis," Longmans, Green and Co., London, 1961. 